Check for updates

Cite this: RSC Adv., 2017, 7, 44132

Received 21st August 2017

Accepted 6th September 2017

DOI: $10.1039 / \mathrm{c} 7 \mathrm{ra09214h}$

rsc.li/rsc-advances

\title{
Synthesis of pyrrolo[1,2-a]quinoxalines via copper or iron-catalyzed aerobic oxidative carboamination of $\mathrm{sp}^{3} \mathrm{C}-\mathrm{H}$ bonds $\uparrow$
}

\author{
Chenshu Dai, Siqi Deng, Qiuhua Zhu (iD * and Xiaodong Tang (D) *
}

\begin{abstract}
An aerobic oxidative carboamination of $\mathrm{sp}^{3} \mathrm{C}-\mathrm{H}$ bonds with 2-(1H-pyrrol-1-yl)anilines has been developed. The oxidative carboamination processes utilized simple and readily available starting materials to produce pyrrolo[1,2-a]quinoxalines in good to moderate yields. The transformations also featured inexpensive metal catalysts (copper or iron) and a green oxidant $\left(\mathrm{O}_{2}\right)$.
\end{abstract}

The pyrrolo[1,2-a]quinoxalines are an important class of heterocyclic compounds which are present in various biologically active agents. For example, some substituted pyrrolo[1,2-a] quinoxaline derivatives promised utilization for novel and highly potent $5-\mathrm{HT}_{3}$ receptor agonists. ${ }^{1}$ And 4 -substituted pyrrolo[1,2-a]quinoxalines could specifically inhibit the D-loop activity of RAD51. ${ }^{2 a}$ Recently, Mai, Steegborn et al. presented a good work about using pyrrolo[1,2-a]quinoxaline derivatives as Sirt6 activators. ${ }^{2 b}$ Furthermore, many pyrrolo[1,2-a]quinoxaline derivatives have been proven to possess other biological activities, including antimalarial activity, ${ }^{3}$ antitumor activity, ${ }^{4}$ HIV-1 reverse transcriptase inhibitors, ${ }^{5}$ human protein kinase CK2 inhibitors, ${ }^{6}$ PARP-1 inhibitors, ${ }^{7}$ non-peptide glucagon receptor antagonists, ${ }^{8}$ and so on. They are also used as fluorescent probes for amyloid fibril. ${ }^{9}$ In 1965, Cheesman and Tuck groups firstly presented the method for the synthesis of pyrrolo [1,2-a]quinoxaline compounds via the reactions between 2- $\left(1 H^{-}\right.$ pyrrol-1-yl)anilines and formic acid under reflux conditions (Scheme 1a). ${ }^{10}$ Afterward, many protocols for the preparation of pyrrolo[1,2-a]quinoxalines have been developed one after another. ${ }^{11}$ Among them, the cyclization reactions involving 2(1H-pyrrol-1-yl)anilines have always been the most active part. And it was most reported to utilize 2 -( $1 H$-pyrrol-1-yl)anilines and aldehydes as the starting materials (Scheme 1b). ${ }^{11 e-g}$ However, these methods suffered from some drawbacks such as tedious procedure, strong oxidant, poor substrate applicability, and so on. In 2017, Jiang and co-workers reported a green aerobic oxidative synthesis of pyrrolo[1,2-a]quinoxalines from simple alcohols (Scheme 1c). ${ }^{11 h}$ However, the transformation

Guangdong Provincial Key Laboratory of New Drug Screening, School of Pharmaceutical Sciences, Southern Medical University, 1023 South Shatai Road, Baiyun District, Guangzhou 510515, P. R. China. E-mail: zhuqh@smu.edu.cn; tangxdong@smu.edu.cn

$\dagger$ Electronic supplementary information (ESI) available: Experimental section, characterization of all compounds, Fig. S1, copies of ${ }^{1} \mathrm{H}$ and ${ }^{13} \mathrm{C}$ NMR spectra for all target compounds. See DOI: 10.1039/c7ra09214h was just suitable for alkyl alcohols, and required alcohols as solvents and high reaction temperature. Subsequently, a method which utilized DMSO not only as solvent but also as the substrate for the synthesis of pyrrolo[1,2-a]quinoxalines was reported by Ma (Scheme 1d). ${ }^{11 i}$ This was a good transformation but only C4 no-substituted products were obtained. Therefore, it is highly desirable to develop new method for the construction of this important skeleton.

On the other hand, direct transformations of inert chemical bonds especially $\mathrm{sp}^{3} \mathrm{C}-\mathrm{H}$ bonds play an important role in sustainable chemistry. ${ }^{12} \mathrm{~A}$ copper $/ \mathrm{O}_{2}$ system could be viewed as an ideal reaction system for carbon-carbon and carbonheteroatom bonds formation because copper catalysts are inexpensive and low-toxic and molecular oxygen as an oxidant is
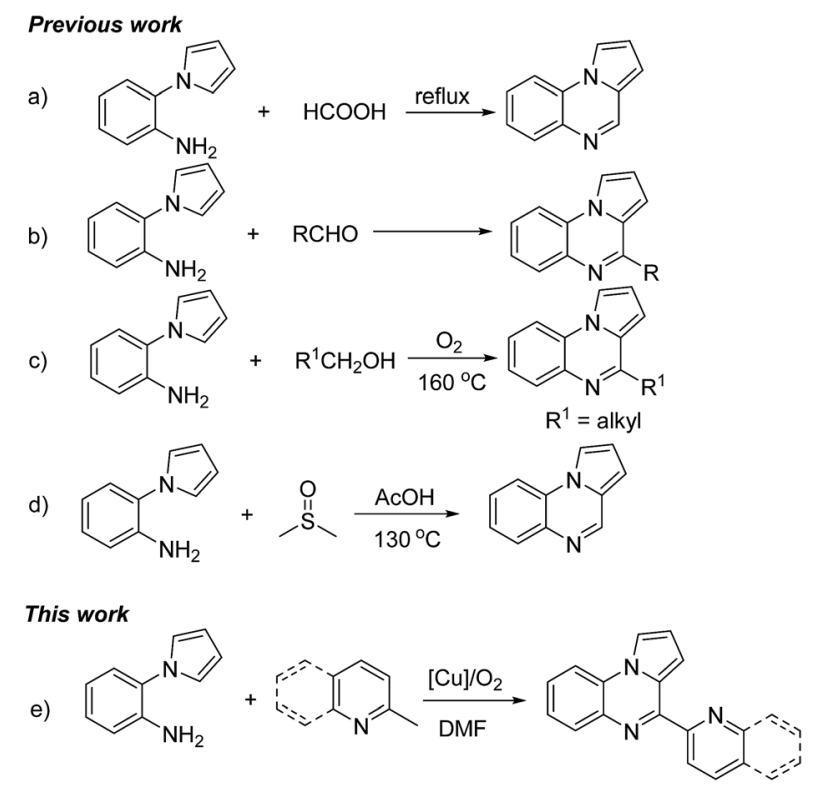

Scheme 1 Synthesis of pyrrolo[1,2-a]quinoxalines from 1-(2-aminophenyl)pyrrole. 
easily available and environment friendly. ${ }^{13}$ Recently, the aerobic copper-catalyzed transformations of methylhetarenes have attracted increasing attention, such as esterification, ${ }^{\mathbf{1 4 a}}$ amidation, ${ }^{14 b, c}$ oxygenation, ${ }^{14 d, e}$ oxidative cross-coupling. ${ }^{14 f-h}$ However, it remains scarce that applying these reactions to construct $N$-heterocycles. ${ }^{14 i, j}$ Herein, we disclose a new aerobic copper-catalyzed cyclization reaction of 2-methylpyridine/ quinoline with 2 -(1H-pyrrol-1-yl)anilines for synthesis of pyrrolo[1,2-a]quinoxalines (Scheme 1e).

Initially, the reaction of 2 -(1H-pyrrol-1-yl)aniline 1 a $(0.3$ mmol) with 2-methylpyridine $2 \mathrm{a}(0.6 \mathrm{mmol})$ in $3 \mathrm{~mL}$ solvent for $12 \mathrm{~h}$ under $\mathrm{a}_{2}$ atmosphere was chosen as the model reaction to examine various reaction parameters and the results were summarized in Table 1 . Our experiment began by reacting 1a and $2 \mathrm{a}$ in $\mathrm{DMF}$ at $120{ }^{\circ} \mathrm{C}$ in the presence of $\mathrm{Cu}(\mathrm{OTf})_{2}(0.06$ $\mathrm{mmol})$ and TFA $(0.3 \mathrm{mmol})$. To our delight, the target product 4 (pyridin-2-yl)pyrrolo[1,2-a]quinoxaline (3a) was obtained in 48\% yield (entry 1). Several other copper salts were then screened, including $\mathrm{Cu}(\mathrm{OAc})_{2}, \mathrm{CuCl}_{2}, \mathrm{CuBr}_{2}, \mathrm{Cu}\left(\mathrm{NO}_{3}\right)_{2}, \mathrm{CuCl}, \mathrm{CuI}, \mathrm{CuBr}$ and $\mathrm{CuCN}$. Our experimental results showed that all copper catalysts could catalyze the transformation to some extent and $\mathrm{Cu}(\mathrm{OAc})_{2}$ was most efficient (entries 2-9). Among the solvents tested, DMF was found to be the most effective in comparison to

Table 1 Optimization of the reaction conditions ${ }^{a}$

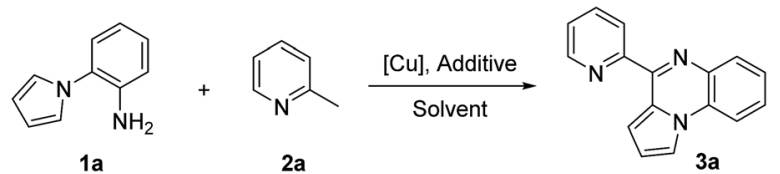

\begin{tabular}{|c|c|c|c|c|}
\hline Entry & {$[\mathrm{Cu}]$} & Additive & Solvent & Yield (\%) \\
\hline 1 & $\mathrm{Cu}(\mathrm{OTf})_{2}$ & TFA & DMF & 48 \\
\hline 2 & $\mathrm{Cu}(\mathrm{OAc})_{2}$ & TFA & $\mathrm{DMF}$ & 78 \\
\hline 3 & $\mathrm{CuCl}_{2}$ & TFA & DMF & 64 \\
\hline 4 & $\mathrm{CuBr}_{2}$ & TFA & DMF & 67 \\
\hline 5 & $\mathrm{Cu}\left(\mathrm{NO}_{3}\right)_{2}$ & TFA & DMF & 70 \\
\hline 6 & $\mathrm{CuCl}$ & TFA & DMF & 65 \\
\hline 7 & $\mathrm{CuI}$ & TFA & DMF & 45 \\
\hline 8 & $\mathrm{CuBr}$ & TFA & DMF & 54 \\
\hline 9 & $\mathrm{CuCN}$ & TFA & DMF & 52 \\
\hline 10 & $\mathrm{Cu}(\mathrm{OAc})_{2}$ & TFA & DMSO & 63 \\
\hline 11 & $\mathrm{Cu}(\mathrm{OAc})_{2}$ & TFA & PhCl & n.d. \\
\hline 12 & $\mathrm{Cu}(\mathrm{OAc})_{2}$ & TFA & Toluene & n.d. \\
\hline 13 & $\mathrm{Cu}(\mathrm{OAc})_{2}$ & $\mathrm{AcOH}$ & DMF & 37 \\
\hline 14 & $\mathrm{Cu}(\mathrm{OAc})_{2}$ & $\mathrm{Ph}_{2} \mathrm{PO}_{2} \mathrm{H}$ & DMF & 41 \\
\hline 15 & $\mathrm{Cu}(\mathrm{OAc})_{2}$ & TfOH & DMF & 56 \\
\hline 16 & - & TFA & DMF & n.d. \\
\hline 17 & $\mathrm{Cu}(\mathrm{OAc})_{2}$ & - & DMF & 15 \\
\hline $18^{b}$ & $\mathrm{Cu}(\mathrm{OAc})_{2}$ & TFA & DMF & 68 \\
\hline $19^{c}$ & $\mathrm{Cu}(\mathrm{OAc})_{2}$ & TFA & DMF & 59 \\
\hline $20^{d}$ & $\mathrm{Cu}(\mathrm{OAc})_{2}$ & TFA & DMF & 64 \\
\hline $21^{e}$ & $\mathrm{Cu}(\mathrm{OAc})_{2}$ & TFA & DMF & n.d. \\
\hline
\end{tabular}

${ }^{a}$ Reaction were performed with $1 \mathrm{a}(0.3 \mathrm{mmol}), \mathbf{2 a}(0.6 \mathrm{mmol}),[\mathrm{Cu}](0.06$ $\mathrm{mmol})$, acid $(0.3 \mathrm{mmol})$ in solvent $(3.0 \mathrm{~mL})$ under $\mathrm{O}_{2}$ atmosphere for 12 h. Isolated yield. n.d. $=$ not determined. ${ }^{b}$ The reaction temperature was $110^{\circ} \mathrm{C} .{ }^{c}$ The reaction temperature was $130{ }^{\circ} \mathrm{C} .{ }^{d}$ The reaction was under air. ${ }^{e}$ The reaction was under $\mathrm{N}_{2}$ atmosphere.
DMSO, PhCl, and toluene (entries 10-12). Different acids, such as $\mathrm{AcOH}, \mathrm{Ph}_{2} \mathrm{PO}_{2} \mathrm{H}$ and $\mathrm{TfOH}$ were investigated, and the results indicated that they were no better than TFA (entries 13-15). When the reaction was carried out in the absence of a copper catalyst, no product was formed and if the reaction proceeded without the acid, the yield of the desired heterocyclic product was very low (entries 16-17). The increase or decrease of reaction temperature led to a diminished yield (entries 18-19). Lower yield was obtained when the reaction was conducted in the oper air (entry 20). Furthermore, no product was obtained under $\mathrm{N}_{2}$ atmosphere (entry 21). Thus, the optimized reaction system for this aerobic oxidative carboamination reaction was: 1a $(0.3 \mathrm{mmol}), 2 \mathrm{a}(0.6 \mathrm{mmol}), \mathrm{Cu}(\mathrm{OAc})_{2}(0.06 \mathrm{mmol})$, TFA (0.3 $\mathrm{mmol})$, and $\mathrm{DMF}(3 \mathrm{~mL})$ under $\mathrm{O}_{2}$ atmosphere at $120{ }^{\circ} \mathrm{C}$ for $12 \mathrm{~h}$.

With the optimal conditions established (Table 1, entry 2), we started to examine the reaction scope of the present transformation and the results were summarized in Table 2 . Various 2-methylpyridine reacted with 2-(1H-pyrrol-1-yl)aniline were firstly examined and all of the reactions afforded the corresponding pyrrolo[1,2-a]quinoxalines in moderate yields (Table 2, 3a-3e). When 2-methylquinoline was used as substrate, the yield of product was up to $85 \%$ (Table 2, 3f). Similarly, 2,6dimethylquinoline, 6-fluoro-2-methylquinoline and 7-fluoro-2methylquinoline also gave the expected cyclization products $3 \mathrm{~g}, 3 \mathbf{h}$ and $3 \mathbf{i}$ in $72 \%, 58 \%$ and $54 \%$ yields, respectively. Finally, the reaction of 5-methyl-2-(1H-pyrrol-1-yl)aniline with 2-methylquinoline could produce 7-methyl-4-(quinolin-2-yl)pyrrolo $[1,2-a]$ quinoxaline in $67 \%$ yield (Table $2,3 \mathbf{j}$ ).

It was amazing that the product pyrrolo[1,2-a]quinoxaline 4 a was formed when we treated 1a with Fe catalyst in DMSO, which

Table 2 Substrate scope of pyrrolo[1,2-a]quinoxalines via coppercatalyzed cyclization reaction ${ }^{a}$

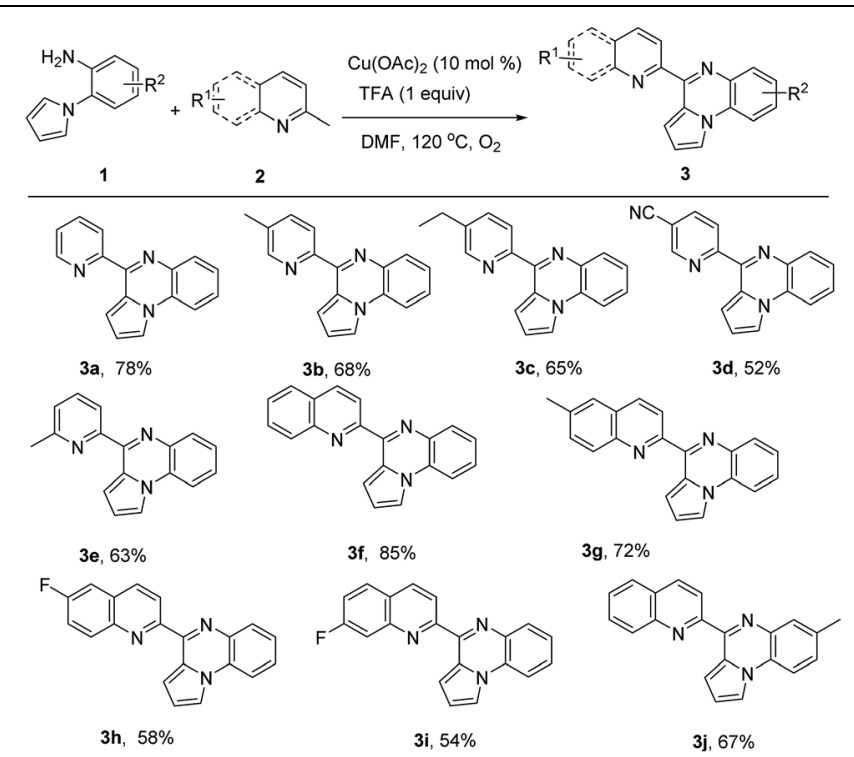

${ }^{a}$ Reactions were performed with $1(0.3 \mathrm{mmol}), 2(0.6 \mathrm{mmol}), \mathrm{Cu}(\mathrm{OAc})_{2}$ $(20 \mathrm{~mol} \%)$, TFA $(0.3 \mathrm{mmol})$ and $\operatorname{DMF}(3 \mathrm{~mL})$ at $120{ }^{\circ} \mathrm{C}$ under $\mathrm{O}_{2}$ atmosphere for $12 \mathrm{~h}$. Yields referred to isolated yields. 
Table 3 Substrate scope of pyrrolo[1,2-a]quinoxalines via iron-catalyzed cyclization reaction ${ }^{a}$

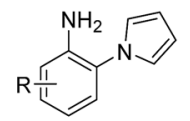

1
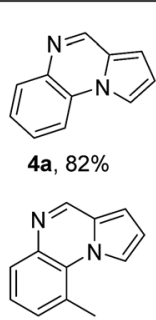

4d, $75 \%$

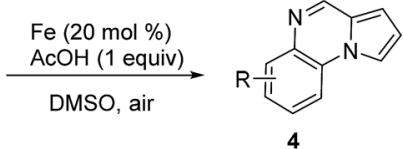

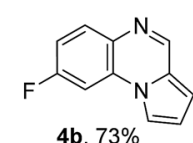

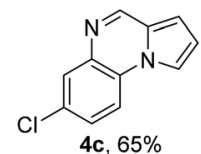

4b, $73 \%$

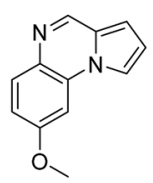

4 e, $45 \%$
${ }^{a}$ Reaction conditions: 1 (0.3 mmol), Fe(0) (20 mol\%), AcOH (0.3 mmol), and DMSO $(3 \mathrm{~mL})$ at $100{ }^{\circ} \mathrm{C}$ under air atmosphere for $12 \mathrm{~h}$. Yields referred to isolated yields.

revealed that DMSO also served as $\mathrm{C} 1$ source in the oxidative cyclization reaction. Compared with previous work, ${ }^{11 i}$ our reaction proceeded with lower reaction temperature. Where after, we optimized the reaction conditions based on Fe catalyst and the best reaction condition were as follows: $1 \mathrm{a}(0.3 \mathrm{mmol})$, $\mathrm{Fe}(0)(20 \mathrm{~mol} \%), \mathrm{AcOH}(0.3 \mathrm{mmol})$ in DMSO $(3 \mathrm{~mL})$ at $100{ }^{\circ} \mathrm{C}$ for $12 \mathrm{~h}$ (see the ESI $\uparrow$ for details). Then, various 2-(1H-pyrrol-1-yl) aniline 1 were examined in the cyclization reaction and the results were summarized in Table 3 . Different substituted 2- $\left(1 H^{-}\right.$ pyrrol-1-yl)aniline could be converted into the corresponding pyrrolo[1,2-a]quinoxaline in moderate to good yields, and electron-withdrawing groups did not show a positive effect on our reaction (Table $3, \mathbf{4 a - 4 e )}$.

To gain more insight into the mechanism, some control experiments shown in Scheme 2 were carried out. Firstly, the reaction of 1a and 2a under standard conditions was interrupted after $1.0 \mathrm{~h}$ to analyze the intermediates (Scheme 2, eqn
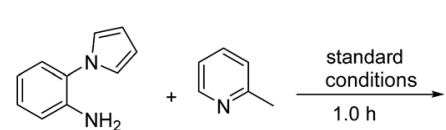

1a, $0.3 \mathrm{mmol}$

2a, $0.6 \mathrm{mmo}$
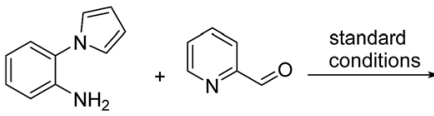

1a, $0.3 \mathrm{mmol}$

5a, $0.6 \mathrm{mmol}$

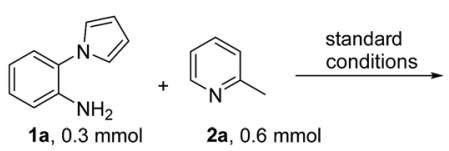

Scheme 2 Control experiments.

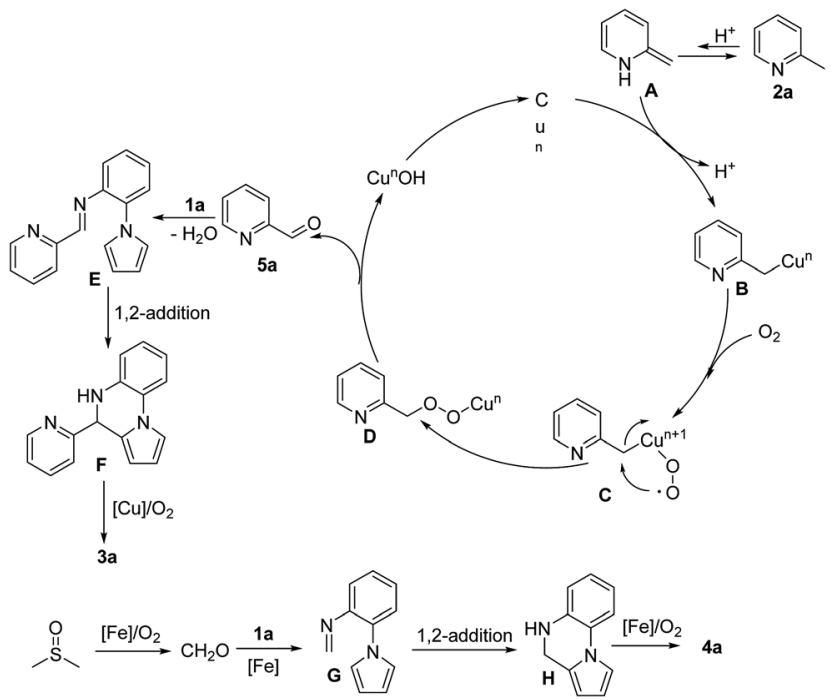

Scheme 3 Possible reaction mechanism.

(1)). Except for the generation of the product 3a (32\% yield), 2pyridinecarboxaldehyde 5 a was obtained in $10 \%$ yield. When 2pyridinecarboxaldehyde $\mathbf{5 a}$ was allowed to react with $\mathbf{1 a}$, the pyrrolo[1,2-a]quinoxalins 3a was formed in $81 \%$ yield (Scheme 2 , eqn (2)). These results indicated that $\mathbf{5 a}$ perhaps served as the key intermediate in the cyclization reaction. When we added a radical-trapping reagent (TEMPO) or a radical inhibitor (BHT) to the reaction system, no product was detected. These observations demonstrated that there should be a radical pathway in this reaction.

According to previous studies ${ }^{11,14}$ and our experimental results above, we proposed the mechanism shown in Scheme 3. Initially, 1a isomerizes to a nonaromatic enamine intermediate $\mathbf{A}$ in the presence of acid. ${ }^{14 a, b, i, j}$ Where after, intermediate $\mathbf{A}$ reacts with the copper species to afford intermediate $\mathbf{B}$ and further combines with the oxygen to generates peroxycopper intermediate $\mathbf{C}{ }^{14 b, j}$ Intermediate $\mathbf{C}$ transforms to intermediate D and subsequent elimination of $\mathrm{Cu}^{n} \mathrm{OH}$ produces aldehyde $5 a^{14 b, j}$ DMSO could decompose and produce $\mathrm{CH}_{2} \mathrm{O}$ in the presence of Fe catalyst with $\mathrm{O}_{2} \cdot{ }^{11 i, 14 k, 14 l}$ The imine intermediate $\mathbf{E}$ or $\mathbf{G}$ is formed by dehydration condensation of $5 \mathbf{a}$ or $\mathrm{CH}_{2} \mathrm{O}$ with 1a, which cyclize to generate intermediate $\mathbf{F}$ or $\mathbf{H}$ through intramolecular Mannich reaction. ${ }^{11 g}$ Finally, oxidation of intermediate $\mathbf{F}$ or $\mathbf{H}$ provides the final product $3 \mathbf{a}$ or $\mathbf{4 a} .{ }^{11 e-g}$

In conclusion, we have developed a copper or iron-catalyzed direct aerobic oxidative carboamination of $\mathrm{sp}^{3} \mathrm{C}-\mathrm{H}$ bonds with 2-(1H-pyrrol-1-yl)aniline. These methods afforded a novel approach for the construction of biologically important pyrrolo $[1,2-a]$ quinoxaline skeleton from readily available materials using inexpensive metal catalysts and green oxidant $\left(\mathrm{O}_{2}\right)$. Further research for the mechanism and the synthetic applications are ongoing in our laboratory.

\section{Conflicts of interest}

There are no conflicts to declare. 


\section{Acknowledgements}

The authors thank the National Natural Science Foundation of China (21702096), the High-level Talent Introduction Foundation of Southern Medical University (C1033520), and the Science and Technology Program of Guangdong Province (2015A010105015) for financial support.

\section{Notes and references}

1 (a) G. Campiani, A. Cappelli, V. Nacci, M. Anzini, S. Vomero, M. Hamon, A. Cagnotto, C. Fracasso, C. Uboldi, S. Caccia, S. Consolo and T. Mennini, J. Med. Chem., 1997, 40, 3670; (b) H. Prunier, S. Rault, J.-C. Lancelot, M. Robba, P. Renard, P. Delagrange, B. Pfeiffer, D.-H. Caignard, R. Misslin, B. Guardiola-Lemaitre and M. Hamon, J. Med. Chem., 1997, 40, 1808; (c) E. Morelli, S. Gemma, R. Budriesi, G. Campiani, E. Novellino, C. Fattorusso, B. Catalanotti, S. S. Coccone, S. Ros, G. Borrelli, V. Kumar, M. Persico, I. Fiorini, V. Nacci, P. Ioan, A. Chiarini, M. Hamon, A. Cagnotto, T. Mennini, C. Fracasso, M. Colovic, S. Caccia and S. Butini, J. Med. Chem., 2009, 52, 3548.

2 (a) W. Lv, B. Budke, M. Pawlowski, P. P. Connell and A. P. Kozikowski, J. Med. Chem., 2016, 59, 4511; (b) W. You, D. Rotili, T.-M. Li, C. Kambach, M. Meleshin, M. Schutkowski, K. F. Chua, A. Mai and C. Steegborn, Angew. Chem., Int. Ed., 2017, 56, 1007.

3 (a) J. Guillon, P. Grellier, M. Labaied, P. Sonnet, J.-M. Léger, R. Déprez-Poulain, I. Forfar-Bares, P. Dallemagne, N. LemaÎtre, F. Péhourcq, J. Rochette, C. Sergheraert and C. Jarry, J. Med. Chem., 2004, 47, 1997; (b) J. Guillon, E. Mouray, S. Moreau, C. Mullié, I. Forfar, V. Desplat, S. Belisle-Fabre, N. Pinaud, F. Ravanello, A. Le-Naour, J.-M. Léger, G. Gosmann, C. Jarry, G. Déléris, P. Sonnet and P. Grellier, Eur. J. Med. Chem., 2011, 46, 2310; (c) J. Guillon, S. Moreau, E. Mouray, V. Sinou, I. Forfar, S. B. Fabre, V. Desplat, P. Millet, D. Parzy, C. Jarry and P. Grellier, Bioorg. Med. Chem., 2008, 16, 9133.

4 (a) F. Grande, F. Aiello, O. D. Grazia, A. Brizzi, A. Garofalo and N. Neamati, Bioorg. Med. Chem., 2007, 15, 288; (b) P. V. Babu, S. Mukherjee, G. S. Deora, K. S. Chennubhotla, R. Medisetti, S. Yellanki, P. Kulkarni, S. Sripelly, K. V. L. Parsa, K. Chatti, K. Mukkanti and M. Pal, Org. Biomol. Chem., 2013, 11, 6680.

5 G. Campiani, F. Aiello, M. Fabbrini, E. Morelli, A. Ramunno, S. Armaroli, V. Nacci, A. Garofalo, G. Greco, E. Novellino, G. Maga, S. Spadari, A. Bergamini, L. Ventura, B. Bongiovanni, M. Capozzi, F. Bolacchi, S. Marini, M. Coletta, G. Guiso and S. Caccia, J. Med. Chem., 2001, 44, 305.

6 J. Guillon, M. L. Borgne, C. Rimbault, S. Moreau, S. Savrimoutou, N. Pinaud, S. Baratin, M. Marchivie, S. Roche, A. Bollacke, A. Pecci, L. Alvarez, V. Desplat and J. Jose, Eur. J. Med. Chem., 2013, 65, 205.

7 J. Miyashiro, K. W. Woods, C. H. Park, X. Liu, Y. Shi, E. F. Johnson, J. J. Bouska, A. M. Olson, Y. Luo, E. H. Fry, V. L. Giranda and T. D. Penning, Bioorg. Med. Chem. Lett., 2009, 19, 4050 .
8 J. Guillom, P. Dallemagne, B. Pfeiffer, P. Renard, D. Manechez, A. Kervran and S. Rault, Eur. J. Med. Chem., 1998, 33, 293.

9 S. Gemma, L. Colombo, G. Forloni, L. Savini, C. Fracasso, S. Caccia, M. Salmona, M. Brindisi, B. P. Joshi, P. Tripaldi, G. Giorgi, O. Taglialatela-Scafati, E. Novellino, I. Fiorini, G. Campiani and S. Butini, Org. Biomol. Chem., 2011, 9, 5137. 10 G. W. H. Cheeseman and B. Tuck, Chem. Ind., 1965, 1382.

11 (a) Z. Zhang, J. Li, G. Zhang, N. Ma, Q. Liu and T. Liu, J. Org. Chem., 2015, 80, 6875; (b) H. Liu, T. Duan, Z. Zhang, C. Xie and C. Ma, Org. Lett., 2015, 17, 2932; (c) J. T. Reeves, D. R. Fandrick, Z. Tan, J. J. Song, H. Lee, N. K. Yee and C. H. Senanayake, J. Org. Chem., 2010, 75, 992; (d) M. F. Pereira and V. Thiéry, Org. Lett., 2012, 14, 4754; (e) A. Preetam and M. Nath, $R S C A d v ., 2015,5,21843$; $(f)$ A. K. Verma, R. R. Jha, V. K. Sankar, T. Aggarwal, R. P. Singh and R. Chandra, Eur. J. Org. Chem., 2011, 6998; (g) C. Wang, Y. Li, J. Zhao, B. Cheng, H. Wang and H. Zhai, Tetrahedron Lett., 2016, 57, 3908; (h) J. Li, J. Zhang, H. Yang, Z. Gao and G. Jiang, J. Org. Chem., 2017, 82, 765; (i) C. Xie, Z. Zhang, D. Li, J. Gong, X. Han, X. Liu and C. Ma, J. Org. Chem., 2017, 82, 3491; (j) Z. He, M. Bae, J. $\mathrm{Wu}$ and T. F. Jamison, Angew. Chem., Int. Ed., 2014, 53, 14451; (k) A. A. Kalinin and V. A. Mamedov, Chem. Heterocycl. Compd., 2011, 46, 1423; (l) M. Wang, C. Liu and Y. Gu, Tetrahedron, 2016, 72, 6854; $(m)$ M. Piltan, Chin. Chem. Lett., 2014, 25, 1507; (n) Y. Harrak, S. Weber, A. B. Gómez, G. Rosell and M. D. Pujol, ARKIVOC, 2007, 251. 12 For selected reviews: (a) S. A. Girard, T. Knauber and C.-J. Li, Angew. Chem., Int. Ed., 2014, 53, 74; (b) R. A. Baillie and P. Legzdins, Acc. Chem. Res., 2014, 47, 330; (c) P. B. Arockiam, C. Bruneau and P. H. Dixneuf, Chem. Rev., 2012, 112, 5879.

13 For selected reviews: (a) A. E. Wendlandt, A. M. Suess and S. S. Stahl, Angew. Chem., Int. Ed., 2011, 50, 11062; (b) S. D. McCann and S. S. Stahl, Acc. Chem. Res., 2015, 48, 1756; (c) S. E. Allen, R. R. Walvoord, R. Padilla-Salinas and M. C. Kozlowski, Chem. Rev., 2013, 113, 6234; (d) X.-X. Guo, D.-W. Gu, Z. Wu and W. Zhang, Chem. Rev., 2015, 115, 1622. 14 (a) M. Liu, T. Chen and S.-F. Yin, Catal. Sci. Technol., 2016, 6, 690; (b) H. Xie, Y. Liao, S. Chen, Y. Chen and G.-J. Deng, Org. Biomol. Chem., 2015, 13, 6944; (c) Y. Huang, T. Chen, Q. Li, Y. Zhou and S.-F. Yin, Org. Biomol. Chem., 2015, 13, 7289; (d) G. Zheng, H. Liu and M. Wang, Chin. J. Chem., 2016, 34, 519; (e) J. Liu, X. Zhang, H. Yi, C. Liu, R. Liu, H. Zhang, K. Zhuo and A. Lei, Angew. Chem., Int. Ed., 2015, 54, 1261; (f) Z.-Q. Zhu, P. Bai and Z.-Z. Huang, Org. Lett., 2014, 16, 4881; $(g)$ S. Lei, Y. Mai, C. Yan, J. Mao and H. Cao, Org. Lett., 2016, 18, 3582; (h) F.-F. Wang, C.-P. Luo, G. Deng and L. Yang, Green Chem., 2014, 16, 2428; (i) Z. Tan, H. Zhao, C. Zhou, H. Jiang and M. Zhang, J. Org. Chem., 2016, 81, 9939; (j) Q. Li, Y. Huang, T. Chen, Y. Zhou, Q. Xu, S.-F. Yin and L.-B. Han, Org. Lett., 2014, 16, 3672; (k) Z. Zhang, Q. Tian, J. Qian, Q. Liu, T. Liu, L. Shi and G. Zhang, J. Org. Chem., 2014, 79, 8182; (l) S. Xiang, H. Chen and Q. Liu, Tetrahedron Lett., 2016, 57, 3870. 